\title{
Arctiini Leach, [1815] (Lepidoptera, Erebidae, Arctiinae) of the Amazônia National Park, Pará, Brazil
}

\author{
José Augusto Teston ${ }^{1,2 \%}$ \\ Margarida Pereira de Freitas ${ }^{2}$ \\ Ana Carla Walfredo da Conceição ${ }^{2}$ \\ Danúbia Marcela Pereira Valente ${ }^{2}$ \\ Universidade Federal do Oeste do Pará \\ ${ }^{1}$ Instituto de Ciências da Educação, Laboratório de Estudos de Lepidópteros Neotropicais \\ Rua Vera Paz s/n, CEP 68.040-255, Santarém - PA, Brasil \\ ${ }^{2}$ Programa de Pós-Graduação em Biodiversidade e Biotecnologia - Rede Bionorte \\ Santarém - PA, Brasil \\ * Autor para correspondência \\ jateston@gmail.com
}

Submetido em 03/04/2020

Aceito para publicação em 25/06/2020

\section{Resumo}

Arctiini Leach, [1815] (Lepidoptera, Erebidae, Arctiinae) do Parque Nacional da Amazônia, Pará, Brasil. Este estudo avaliou a fauna Arctiini do Parque Nacional da Amazônia (Pará, Brasil), coletada em quatro expedições, entre 11 a 15 de julho e 02 a 06 de outubro de 2013 (estação seca), e entre 01 a 05 de março e 25 a 29 de junho de 2014 (estação chuvosa). Armadilhas luminosas foram usadas uma noite em cada local de amostragem (SS) das $18 \mathrm{~h}$ às $6 \mathrm{~h}$ do dia seguinte. Os parâmetros avaliados foram: riqueza (S), abundância $(\mathrm{N})$, índices de diversidade (H') e uniformidade (E') de Shannon e, dominância de Berger-Parker (BP). A riqueza foi estimada usando os métodos não paramétricos "Chao1, Chao2, ACE, ICE, Jackknife1, Jackknife2 e Bootstrap". Foram capturados 804 espécimes pertencentes a 190 espécies de Arctiini; 22 dessas são novos registros para o estado do Pará e, destes, quatro são novos para a Amazônia brasileira. Os estimadores de riqueza e a curva de acumulação de espécies indicaram a necessidade de maiores esforços de amostragem na área.

Palavras-chave: Mariposas-tigre; Mariposas-vespa; Noctuoidea

\section{Abstract}

This study evaluated the Arctiini fauna of the Amazônia National Park (Pará, Brazil) collected in four expeditions between July 11 to 15 and October 02 to 06, 2013 (dry season), and March 01 to 05 and June 25 to 29, 2014 (rainy season). Light traps were left one night in each sampling site (SS) from 6pm to 6am of the following day. The following parameters were evaluated: richness $(\mathrm{S})$, abundance $(\mathrm{N})$, diversity index $\left(\mathrm{H}^{\prime}\right)$, Shannon evenness (E') index, and Berger-Parker dominance (BP). Richness was estimated using the nonparametric methods "Chao1, Chao2, ACE, ICE, Jackknife1, Jackknife2 and Bootstrap". A total of 804 specimens were captured, belonging to 190 Arctiini taxa; 22 of these are new records for the state of Pará and, of these, four are new records for the Brazilian Amazon. The richness estimators and accumulation curve indicated the need for increased sampling efforts in the area.

Key words: Noctuoidea; Tiger moths; Wasp Moths 


\section{Introduction}

There are many articles that highlight the Amazonian biodiversity and its mega-diversity in species, landscapes, and ecosystems, as well as its fundamental importance in global climate regulation. In fact, the Amazon is the largest rainforest in the world, covering an area of approximately $6,000,000 \mathrm{~km}^{2}$ and stands out for having the highest diversity of animals and plants on the planet (BOUBLI; HRBEK, 2012).

The Protected Areas (PAs) have been key to the preservation in situ of nature. PAs have slowed down deforestation, which is more intense along the southern and eastern borders of the Amazon region and have mitigated land-use pressures such as illegal deforestation and the irregular occupation of land (BERNARD et al., 2014).

According to Carvalho et al. (2016), the municipality of Itaituba, where most of the Amazônia National Park (AMZNP) is located, is one of four municipalities in the state of Pará with the highest deforestation rates.

Lepidopterans are one of the main insect orders, and are particularly useful in studies of biodiversity owing to their species richness and economic importance. Due to the phytophagous eating habits of their larvae, they can be used as bioindicators of vegetation quality in a specific area (KITCHING et al., 2000; TESTON et al., 2006). Adults are easily collected with light traps and there are many different models (TESTON et al., 2006; CAMARGO, 2001).

Nocturnal Arctiini are one of the most used Lepidoptera groups for ecosystem monitoring, and many studies have documented its importance (DELFINA; TESTON, 2013; TESTON; CORREA, 2015). Furthermore, some inventories evaluating the Arctiini fauna in protected areas (PAs) have already been made in the main biomes in Brazil (e. g. Amazon, Cerrado and Atlantic Forest) (FERRO; DINIZ, 2007; TESTON; CORREA, 2015; MORENO; FERRO, 2016).

In the Neotropical region, there are 4,761 species of Arctiini (HEPPNER, 1991), and Brown Jr. and Freitas (1999) estimate the occurrence of at least two thousand species in Brazil. The state of Pará alone has
536 recorded species (TESTON et al., 2019). Recently the first study on the Arctiini fauna was carried out in a protected area in the Amazon rainforest in Brazil (TESTON; CORREA, 2015).

With the aim of contributing to a greater understanding of Arctiini diversity in the Brazilian Amazon, primarily in PAs, a survey of the species of this lepidopteran subfamily was undertaken in the Amazônia National Park (AMZNP), Pará, Brazil. Until the present study, there were no records of the occurrence of Arctiini species in the AMZNP. Recently, political pressure has been put on the AMZNP and other federal conservation units to reduce their coverage, their degree of protection, and even their conservation status (BRASIL, 2012; BERNARD et al., 2014).

\section{Material and Methods}

The Amazonia National Park (AMZNP), a conservation unit maintained by the Instituto Chico Mendes de Conservação da Biodiversidade (ICMBio), was created by the Decree of February 19, 1974. With an area of 1,070,736 ha, it is nested in the municipalities of Aveiro and Itaituba, in the state of Pará, and Maués in the state of Amazonas (Figure 1). It is limited to the north by the Andirá-Marau Indigenous Land, to the south by the Amanã National Forest, to the east by the Maués State Forest and the Pau-Rosa National Forest, and to the west by the Tapajós River. The park presents a mosaic of 14 different vegetation types, with the dense lowland rainforest occupying the largest portion, interspersed with a small portion of open rainforest (IBDF, 1978; KASECKER; SILVA, 2011; BRASIL, 2012).

In this region the rainy season extends from December to May, the dry from June to November (MORAES et al., 2005).

Collections were made in four expeditions, with four nights in length each, two during the rainy season and two during the dry season, totaling 16 samples. During the dry season, samples were collected July 11 to 15 and October 02 to 06,2013 , and during the rainy season, March 01 to 05 and June 25 to 29, 2014 (Figure 1; Table 1). To that end, L-shaped light traps (2.0 $\mathrm{m}$ in width 
FIGURE 1: Location of the Amazônia National Park and respective sampling sites (SS), geographic positions according to Table 1 and satellite image by Google Earth Pro.

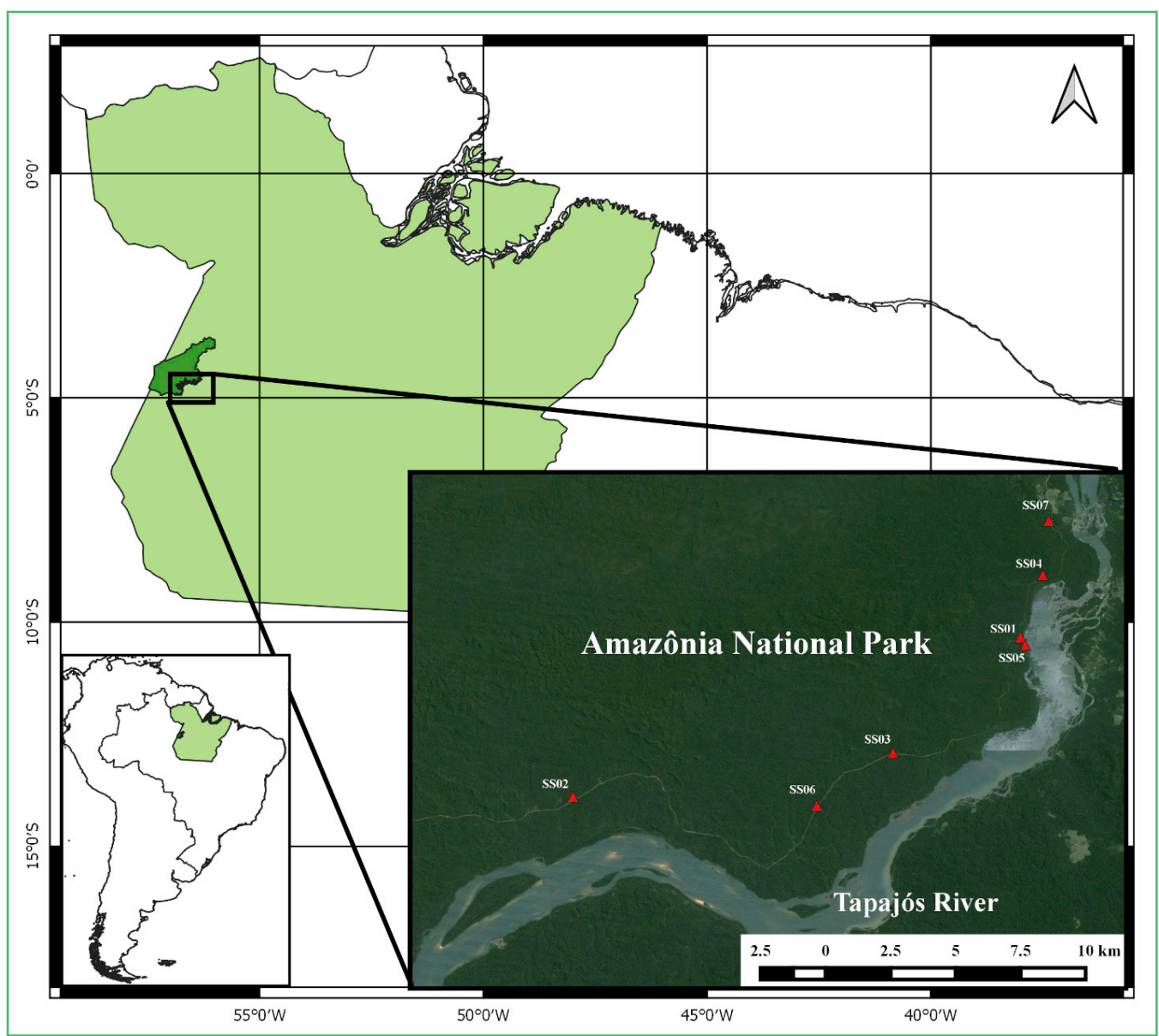

and $2.0 \mathrm{~m}$ length) were made with two white cloths. The moths were captured with killing jars containing Ethyl acetate. Two mixed lamps (250 watts) powered by a portable electric generator (TESTON; CORREA, 2015), one on each cloth, were used to attract the moths. These lights were left on all night, from $6 \mathrm{pm}$ to $6 \mathrm{am}$ of the following day, in a total sampling effort of $12 \mathrm{~h}$ in every sampling site (SS).

The captured Arctiini were separated, counted, and recorded in specific worksheets for every location in the Laboratório de Estudos de Lepidópteros Neotropicais (LELN) of the Universidade Federal do Oeste do Pará (UFOPA). Representative samples of every species (voucher) were prepared following the traditional method for Lepidoptera, and subsequently incorporated into the laboratory collection (LELN).

Species identification was carried out using reference works (HAMPSON, 1898; 1901; 1914; 1920; DRAUDT, 1914-1919; SEITZ, 1919-1925; HERING, 1925; WATSON, 1971; 1973; 1975; 1980) and by comparison with specimens deposited in the collection of the Instituto Nacional de Pesquisas da Amazônia (INPA), Museu Paraense Emílio Goeldi (MPEG), and Laboratório de Estudos de Lepidópteros Neotropicais (LELN). 
TABLE 1: Sampling site (SS), dates (night from 6pm to 6am), season (Dry and Rainy), geographic coordinates and altitude for Arctiini (Lepidoptera, Erebidae, Arctiinae) captured with light traps during the expeditions to the Amazônia National Park, Pará, Brazil.

\begin{tabular}{|c|c|c|c|c|c|}
\hline \multirow{2}{*}{ Sampling site (SS) } & \multirow{2}{*}{ Date (night) } & \multirow{2}{*}{ Season } & \multicolumn{2}{|c|}{ Geographic Coordinates } & \multirow{2}{*}{$\begin{array}{l}\text { Altitude } \\
\text { (m.s.l.) }\end{array}$} \\
\hline & & & Latitude & Longitude & \\
\hline SS01 & $\begin{array}{c}11-12 / \mathrm{VII} / 2013 \\
02-03 / \mathrm{X} / 2013 \\
05-06 / \mathrm{X} / 2013 \\
01-02 / \mathrm{III} / 2014 \\
02-03 / \mathrm{III} / 2014 \\
04-05 / \mathrm{III} / 2014 \\
25-26 / \mathrm{VI} / 2014 \\
28-29 / \mathrm{VI} / 2014\end{array}$ & $\begin{array}{l}\text { Dry } \\
\text { Dry } \\
\text { Dry } \\
\text { Rainy } \\
\text { Rainy } \\
\text { Rainy } \\
\text { Rainy } \\
\text { Rainy }\end{array}$ & $04^{\circ} 32^{\prime} 52.9^{\prime \prime} \mathrm{S}$ & $56^{\circ} 18^{\prime} 11.8^{\prime \prime} \mathrm{W}$ & 80 \\
\hline $\mathrm{SS} 02$ & $\begin{array}{c}12-13 / \mathrm{VII} / 2013 \\
03-04 / \mathrm{X} / 2013 \\
03-04 / \mathrm{III} / 2014\end{array}$ & $\begin{array}{l}\text { Dry } \\
\text { Dry } \\
\text { Rainy }\end{array}$ & $04^{\circ} 39^{\prime} 15^{\prime \prime S}$ & $56^{\circ} 36^{\prime} 10.7^{\prime \prime} \mathrm{W}$ & 57 \\
\hline $\mathrm{SS} 03$ & $13-14 / \mathrm{VII} / 2013$ & Dry & $04^{\circ} 37^{\prime} 30^{\prime \prime S}$ & $56^{\circ} 23^{\prime} 18.9^{\prime \prime} \mathrm{W}$ & 56 \\
\hline SS04 & $14-15 / \mathrm{VII} / 2013$ & Dry & $04^{\circ} 30^{\prime} 23.7^{\prime \prime} \mathrm{S}$ & $56^{\circ} 17^{\prime} 17.5^{\prime \prime} \mathrm{W}$ & 30 \\
\hline SS05 & $04-05 / \mathrm{X} / 2013$ & Dry & $04^{\circ} 33^{\prime} 11.5 ” \mathrm{~S}$ & $56^{\circ} 17^{\prime} 59.9^{\prime \prime} \mathrm{W}$ & 41 \\
\hline SS06 & $26-27 / \mathrm{VI} / 2014$ & Rainy & $04^{\circ} 39^{\prime} 37.1 ” S$ & $56^{\circ} 26^{\prime} 23^{\prime \prime} \mathrm{W}$ & 61 \\
\hline SS07 & $27-28 / \mathrm{VI} / 2014$ & Rainy & $04^{\circ} 28^{\prime} 13.2^{\prime \prime S}$ & $56^{\circ} 17^{\prime} 3.7^{\prime \prime} \mathrm{W}$ & 14 \\
\hline
\end{tabular}

The taxonomic classification adopted and allocation of species to genera follows Vincent and Laguerre (2014) for the subtribes Arctiina, Callimorphina, Phaegopterina, Pericopina, and Spilosomina, and Hampson (1898); Watson et al. (1995) and Weller et al. (2000) for Ctenuchina and Euchromiina.

In order to compare among rainy and dry seasons, a list of the occurrence and abundance $(\mathrm{N})$ of Arctiini was organized in alphabetical order by subtribe, genus, and species. Richness (S), diversity (H') and evenness (E') Shannon indexes, Berger-Parker dominance (BP) (MAGURRAN, 2011), and estimate of species richness by the non-parametric methods Chao1, Chao2, ACE, ICE, Jackknife1, Jackknife2 and Bootstrap, using the program EstimateS (version 9.1.0) (COLWELL, 2013), are presented for rainy and dry seasons and total.

\section{Results}

In total, 804 specimens (N) were captured, distributed in 190 species (S) and representing all seven Arctiini subtribes, with $\mathrm{N}=520$ and $\mathrm{S}=161$ for dry season; and $\mathrm{N}=284$ and $\mathrm{S}=102$ for rainy season (Tables 2 and 3 ).

Of the 190 species sampled, 158 were identified to the species level $(83 \%)$ and 32 at the genus level (17\%) (Table 2). The subtribe with the highest number of species was Phaegopterina (132 species, 69.5\% of the total), followed by Ctenuchina $(27,14.2 \%)$, Euchromiina (23, 12.1\%), Pericopina (4, 2.1\%), Arctiina and Spilosomina (both with 2 species, 1.05\%). 
TABLE 2: Number of Arctiini (Lepidoptera, Erebidae, Arctiinae) specimens captured with light traps during the expeditions to the Amazônia National Park, Pará, Brazil. Species marked with * indicate a first-time record for the state of Pará.

\begin{tabular}{|c|c|c|c|}
\hline Subtribes/Species & Dry & Rainy & Total \\
\hline \multicolumn{4}{|l|}{ Arctiina } \\
\hline Pseudalus salmonaceus (Rothschild, 1909) * & 1 & & 1 \\
\hline Virbia subapicalis (Walker, 1854) & 1 & & 1 \\
\hline \multicolumn{4}{|l|}{ Ctenuchina } \\
\hline Aclytia heber (Cramer, [1780]) & 3 & 1 & 4 \\
\hline Aclytia sp. & 1 & & 1 \\
\hline Correbidia calopteridia (Butler, 1878) & 8 & 3 & 11 \\
\hline Delphyre flaviceps (Druce, 1905) & 1 & 2 & 3 \\
\hline Delphyre roseiceps Dognin, 1909 & 3 & 2 & 5 \\
\hline Epidesma aurimacula (Schaus, 1905) & 1 & & 1 \\
\hline Epidesma parva (Rothschild, 1912) & 1 & & 1 \\
\hline Epidesma perplexa (Rothschild, 1912) * & 2 & & 2 \\
\hline Episcepsis lamia (Butler, 1877) & & 2 & 2 \\
\hline Episcepsis venata Butler, 1877 & 1 & & 1 \\
\hline Episcepsis sp.1 & 2 & 1 & 3 \\
\hline Episcepsis sp.2 & 1 & 1 & 2 \\
\hline Eucereon aoris Möschler, 1877 & 2 & & 2 \\
\hline Eucereon marmoratum Butler, 1877 & 1 & & 1 \\
\hline Eucereon obscura (Möschler, 1872) & 1 & & 1 \\
\hline Eucereon simile Draudt, 1915 & 1 & & 1 \\
\hline Eucereon varia (Walker, 1854) & 3 & & 3 \\
\hline Heliura perexcavatum (Rothschild, 1912) & 5 & & 5 \\
\hline Heliura zonata Druce, 1905 & 1 & 1 & 2 \\
\hline Hyaleucerea erythrotela (Walker, 1854) & 1 & & 1 \\
\hline Hyaleucerea sp. & 1 & & 1 \\
\hline Patreliura capys (Cramer, 1775) & 1 & & 1 \\
\hline Sciopsyche tropica (Walker, 1854) & & 1 & 1 \\
\hline Telioneura glaucopis R. Felder, 1869 & 1 & & 1 \\
\hline Theages leucophaea Walker, 1855 & & 1 & 1 \\
\hline Timalus leucomela (Walker, 1856) & 1 & & 1 \\
\hline Uranophora walkeri (Druce, 1889) & 3 & 1 & 4 \\
\hline \multicolumn{4}{|l|}{ Euchromiina } \\
\hline Calonotos aequimaculatus Zerny, 1931 & 4 & & 4 \\
\hline Cosmosoma consolata (Walker, 1856) & 1 & & 1 \\
\hline Cosmosoma metallescens (Ménétriés, 1857) & 5 & & 5 \\
\hline Cosmosoma sp. & 1 & 3 & 4 \\
\hline Hypocharis sp. & 3 & & 3 \\
\hline Isanthrene porphyria (Walker, 1854) & & 1 & 1 \\
\hline Leucotmemis torrida (Walker, 1854) & & 6 & 6 \\
\hline Leucotmemis varipes (Walker, 1854) & 2 & 1 & 3 \\
\hline
\end{tabular}


Loxophlebia pyrgion (Druce, 1884)

Macrocneme lades (Cramer, [1775])

Macrocneme sp.

Nyridela chalciope (Hübner, 1827)

Pheia albisigna (Walker, 1854)

Poliopastea sp.

Pompiliodes aliena (Walker, 1854)

Pseudomya sp.

Psoloptera leucosticta (Hübner, 1827)

Sarosa acutior (R. Felder, 1869)

Saurita cassandra (Linnaeus, 1758)

Saurita lasiphlebia Dognin, 1906

Saurita pebasa (Kaye, 1918)

Saurita vindonissa (Druce, 1883) *

Saurita sp.

Pericopina

Calodesma dioptis (C. Felder \& R. Felder, 1874)

Chetone catilina (Cramer, [1776])

Hyalurga lauronoides Hering, 1925 *

Hyalurga leucophlebia Hering, 1925

$\begin{array}{ccc} & 1 & 1 \\ 1 & 1 & 2 \\ 1 & & 1 \\ 2 & 2 & 4 \\ 3 & 2 & 5 \\ & 1 & 1 \\ 1 & 2 & 3 \\ 13 & 2 & 15 \\ 1 & 1 & 2 \\ 2 & & 2\end{array}$

\section{Phaegopterina}

Agaraea semivitrea (Rothschild, 1909)

Amaxia beata (Dognin, 1909)

Amaxia bella (Schaus, 1905)

Amaxia chaon (Druce, 1883)

Amaxia consistens Schaus, 1905

Amaxia erythrophleps Hampson, 1901

Amaxia flavicollis (Rothschild, 1909)

Amaxia lepida (Schaus, 1912)

Amaxia pandama (Druce, 1893)

Amaxia pseudodyuna Rothschild, 1922

Amaxia rufobasalis Rothschild, 1909 *

Amaxia sp.1

Amaxia sp.2

Amaxia sp. 3

Ammalo helops (Cramer, [1776])

Ammalo sp.

Aphyle cuneata Hampson, 1905

Apiconoma opposita (Walker, 1854)

Apyre separata Walker, 1854

Araeomolis albipicta (Dognin, 1909) *

Araeomolis propinqua Toulgoët, 1998

Araeomolis rhodographa Hampson, 1901

$\begin{array}{lll}1 & & 1 \\ 1 & & 1 \\ 1 & 5 & 6 \\ 2 & & 2\end{array}$


Arctiarpia melanopasta (Dognin, 1907)

Astralarctia pulverosa (Schaus, 1905)

Azatrephes discalis (Walker, 1856)

Azatrephes fuliginosa Rothschild, 1909 *

Baritius eleutheroides Rothschild, 1909

Baritius sannionis (Rothschild, 1909)

Carales astur (Cramer, [1777])

Carathis sp.

Chrysomallos fulvescens (Rothschild, 1909)

Coiffaitarctia basalis (Rothschild, 1909) *

Cratoplastis diluta Felder \& Rogenhofer, 1874

Cratoplastis rectiradia (Hampson, 1901)

Cresera affinis (Rothschild, 1909)

Cresera hieroglyphica (Schaus, 1905)

Cresera ilioides (Schaus, 1905)

Cresera ilus (Cramer, [1776])

Cresera optimus (Butler, 1877)

Cresera similis (Rothschild, 1909)

Diaphanophora albiscripta (Schaus, 1905)

Echeta semirosea (Walker, [1865])

Echeta trinotata (Reich, 1933) *

Echeta sp.

Emurena fernandezi Watson, 1975

Ernassa cruenta (Rothschild, 1909)

Eucyrta albicollis Felder \& Rogenhofer, 1874

Euplesia sphingidea (Perty, [1833])

Eupseudosoma larissa (Druce, 1890)

Evius albicoxae (Schaus, 1905)

Evius hippia (Stoll, [1790])

Evius sp.

Glaucostola flavida Schaus, 1905

Glaucostola guttipalpis (Walker, 1856) *

Glaucostola maroniensis Joicey \& Talbot, 1918 *

Gorgonidia buckleyi (Druce, 1883)

Haemanota holophaea (Hampson, 1905)

Haemaphlebiella formona (Schaus, 1905) *

Haemaphlebiella strigata Jones, 1914

Himerarctia griseipennis (Rothschild, 1909)

Himerarctia laeta Watson, 1975

Hyperandra appendiculata (Herrich-Schäffer, [1856])

Hyperandra novata (Dognin, 1924)

Hypidalia sanguirena Schaus, 1905 *

Hyponerita persimilis Rothschild, 1909 *
1

2

10

$5 \quad 6$

13

$\begin{array}{lll}10-3 & 13\end{array}$

2

5

1

5

1

2

3

3

5

2

8

2

9

1

1


Hyponerita similis Rothschild, 1909

Idalus admirabilis (Cramer, [1777])

Idalus aleteria (Schaus, 1905)

Idalus critheis Druce, 1884

Idalus fasciipuncta (Rothschild, 1909)

Idalus intermedia (Rothschild, 1909)

Idalus vitrea vitrea (Cramer, [1780])

Idalus sp.

Ischnognatha semiopalina Felder \& Rogenhofer, 1874

Lepidokirbyia venigera Toulgoët, [1983]

Leucanopsis sp.1

Leucanopsis $\mathrm{sp} .2$

Lophocampa albescens (Rothschild, 1909) *

Lophocampa citrina (Sepp, [1852])

Lophocampa modesta (Kirby, 1892)

Lophocampa sp.1

Lophocampa sp.2

Melese drucei Rothschild, 1909

Melese incertus (Walker, 1855)

Melese ocellata Hampson, 1901

Neonerita dorsipuncta Hampson, 1901

Nyearctia leucoptera (Hampson, 1920)

Ordishia klagesi (Rothschild, 1909)

Ordishia sp.

Ormetica packardi (Butler, 1876)

Ormetica stenotis (Dognin, 1908) *

Ormetica sypilus (Cramer, [1777])

Ormetica zenzeroides (Butler, 1877) *

Ormetica sp.

Pachydota albiceps (Walker, 1856)

Parathyris cedonulli (Stoll, [1781])

Phaeomolis polystria (Schaus, 1905)

Premolis semirufa (Walker, 1856)

Pryteria alboatra (Rothschild, 1909)

Pseudepimolis flavonotata (Rothschild, 1909)

Pseudepimolis incisa (Rothschild, 1909) *

Psycophasma erosa (Herrich-Schäffer, [1858])

Rhipha albiplaga (Schaus, 1905)

Robinsonia klagesi Rothschild, 1910 *

Robinsonia mossi (Rothschild, 1922)

Scaptius asteroides (Schaus, 1905)

Scaptius chrysopera (Schaus, 1905)

Selenarctia elissa (Schaus, 1892)

3

(


Stidzaeras strigifera Druce, 1905

Sutonocrea reducta (Walker, 1856)

Symphlebia sp.

Thyromolis pythia (Druce, 1900) *

Toulgoetarctia nigripuncta (Joicey \& Talbot, 1918)

Toulgoetarctia sanguinea (Hampson, 1905)

Trichromia albicollis (Hampson, 1905)

Trichromia declivis (Schaus, 1905)

Trichromia gaudialis (Schaus, 1905)

Trichromia leucoplaga (Hampson, 1905)

Trichromia lophosticta (Schaus, 1911) *

Trichromia metachryseis (Hampson, 1905)

Trichromia onytes (Cramer, [1777])

Trichromia patara (Druce, 1896)

Trichromia rosacea (Rothschild, 1909) *

Trichromia sp.1

Trichromia sp. 3

Trichromia sp.4

Trichromia sp.5

Viviennea moma (Schaus, 1905)

Viviennea superba (Druce, 1883)

Zatrephes trailii Butler, 1877

Zatrephes sp.1

Zatrephes sp.2

\section{Spilosomina}

Paracles laboulbeni (Bar, 1873)

Paracles sp.

\begin{tabular}{|c|}
\hline \multirow[t]{2}{*}{3} \\
\hline \\
\hline 5 \\
\hline 1 \\
\hline 1 \\
\hline 5 \\
\hline 1 \\
\hline 3 \\
\hline 1 \\
\hline 1 \\
\hline 1 \\
\hline 8 \\
\hline 2 \\
\hline
\end{tabular}

17

520

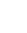

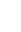
(3)
Melese drucei Rothschild, 1909, and Melese incertus (Walker, 1855) were the most abundant Arctiini collected, with 93 and 56 specimens, respectively.

The Shannon diversity index (Table 3) calculated for the entire sample was $H^{\prime}=4.56$, with evenness $\mathrm{E}^{\prime}=0.869$. As expected, this high value is accompanied by a very low Berger-Parker dominance index $(\mathrm{BP}=0.116)$. Between seasons, the dry season showed higher values $\left(\mathrm{H}^{\prime}=4.49, \mathrm{E}^{\prime}=0.884\right.$ and $\left.\mathrm{BP}=0.102\right)$.
The richness estimators (Table 4) point to an increase in the number of Arctiini species in the AMZNP. In this study, between $84.8 \%$ (Bootstrap) to $65.7 \%$ (Jackknife2) of the total expected species were captured; and between $83 \%$ (Bootstrap) to 59\% (ICE) for dry season and, between $80.3 \%$ (Bootstrap) to $44 \%$ (ICE) for rainy season. The accumulation curve of species (Figure 2) has not stabilized. 
TABLE 3: Richness (S), abundance (N), diversity (H') and evenness (E') of Shannon, Berger-Parker dominance (BP), and sampling nights (SN) by season (Dry and Rainy) for Arctiini (Lepidoptera, Erebidae, Arctiinae) captured with light traps during the expeditions to the Amazônia National Park, Pará, Brazil.

\begin{tabular}{lcccccc}
\hline \multicolumn{1}{c}{ Season } & SN & S & N & H' & E & BP \\
\hline Dry & 8 & 161 & 520 & 4.49 & 0.884 & 0.102 \\
Rainy & 8 & 102 & 284 & 4.03 & 0.872 & 0.141 \\
\hline Total & $\mathbf{1 6}$ & $\mathbf{1 9 0}$ & $\mathbf{8 0 4}$ & $\mathbf{4 . 5 6}$ & $\mathbf{0 . 8 6 9}$ & $\mathbf{0 . 1 1 6}$ \\
\hline
\end{tabular}

TABLE 4: Estimates for Arctiini (Lepidoptera, Erebidae, Arctiinae) captured with light traps during the expeditions to the Amazônia National Park, Pará, Brazil. For total and dry and rainy seasons. Samples, species, uniques, duplicates, singletons, doubletons and species richness by estimators Chao1, Chao2, ACE, ICE, Jackknife1, Jackknife2 and Bootstrap.

\begin{tabular}{lcccccc}
\hline & \multicolumn{2}{c}{ Total } & & Dry & & Rainy \\
\cline { 2 - 7 } & Values & $\begin{array}{c}\text { Percentage of richness } \\
\text { observed in relation to } \\
\text { the estimated }\end{array}$ & Values & $\begin{array}{c}\text { Percentage of richness } \\
\text { observed in relation to } \\
\text { the estimated }\end{array}$ & Values & $\begin{array}{c}\text { Percentage of richness } \\
\text { observed in relation to } \\
\text { the estimated }\end{array}$ \\
\hline Samples & 16 & - & 8 & - & 8 & - \\
Species & 190 & - & 161 & - & 102 & - \\
Uniques & 76 & - & 83 & - & 65 & - \\
Duplicates & 48 & - & 43 & - & 20 & - \\
Singletons & 64 & - & 68 & - & 55 & - \\
Doubletons & 38 & - & 38 & - & 18 & - \\
Chao1 & 242 & 78.5 & 222 & 72.5 & 186 & 54.8 \\
Chao2 & 245 & 77.6 & 231 & 69.7 & 194 & 52.6 \\
ACE & 243 & 78.2 & 233 & 69.1 & 184 & 55.4 \\
ICE & 262 & 72.5 & 273 & 59.0 & 232 & 44.0 \\
Jackknife1 & 261 & 72.8 & 234 & 68.8 & 159 & 64.2 \\
Jackknife2 & 289 & 65.7 & 268 & 60.1 & 195 & 52.3 \\
Bootstrap & 224 & 84.8 & 194 & 83.0 & 127 & 80.3 \\
\hline
\end{tabular}


FIGURE 2: Accumulation curve of Arctiini species in relation to sampling effort employed in the Amazônia National Park. (A) Total; (B) Rainy and (C) Dry seasons.

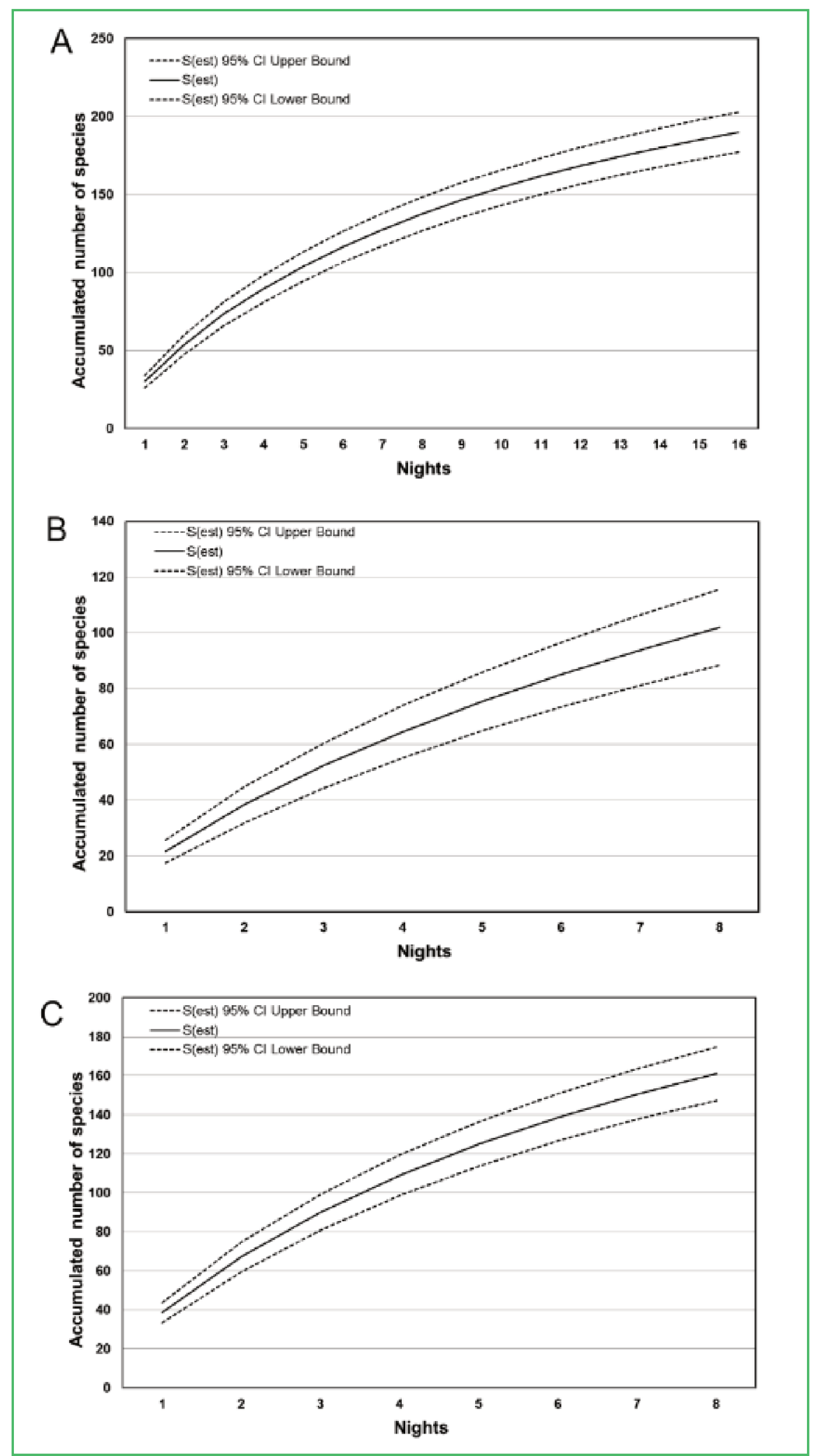




\section{Discussion}

The number of sampled species corresponds to $35.4 \%$ of the total known for the state, according to Teston et al. (2019). A total of 22 species are new records for the state of Pará (denoted by an asterisk in Table 2 ), bringing the number of recorded species to 558. Of these, four are new records for the Brazilian Amazon: Glaucostola maroniensis Joicey \& Talbot, 1918, Lophocampa albescens (Rothschild, 1909), Pseudalus salmonaceus (Rothschild, 1909) and Trichromia lophosticta (Schaus, 1911).

Only seven species represented one third of the total abundance (30.5\%). On the other hand, 64 species $(33.6 \%)$ were represented only by one captured specimen. In previous research, including those conducted in the state of Pará, many Arctiini species were represented by only a few individuals (HAWES et al., 2009; TESTON; DELFINA, 2010; TESTON et al., 2012; DELFINA; TESTON, 2013; TESTON; CORREA, 2015; VALENTE et al., 2018). The same applies to the dry and rainy seasons. In the dry season, eight species represented $31.5 \%$ of the abundance and 68 species $(42 \%)$ with one captured specimen and, in the rainy season, four species represented $28.9 \%$ of the abundance and 55 species (54\%) with one captured specimen (TESTON; DELFINA, 2010; TESTON et al., 2012; DELFINA; TESTON, 2013; VALENTE et al., 2018).

The diversity, equitability and dominance indices follow the trend already observed in other studies in Pará, being more relevant in the dry season (TESTON; DELFINA, 2010; TESTON et al., 2012; DELFINA; TESTON, 2013).

When comparing the richness with other inventory in protected areas (PAs) of other Brazilian biomes (e. g. Cerrado and Atlantic Forest), we note the relevance of the richness found in this study, which was $61 \%$ higher than that found in the Emas National Park $(\mathrm{S}=117)$ in the cerrado (MORENO; FERRO, 2016); and only 19\% fewer species than in the Boraceia Biological Station $(\mathrm{S}=235)$ in the Atlantic Forest, with greater sampling effort (410 nights) (FERRO; DINIZ, 2007).
The accumulation curve of species did not show an asymptote, indicating the need to enlarge the sampling effort. In the same manner, the estimators show that the observed richness varied from $65.7 \%$ (Jackknife2) to $84.8 \%$ (Bootstrap) in relation to the estimated richness, indicating that the inventory must be broadened, consistent with recent Arctiini study carried out in the Serra do Pardo National Park, an important Protected Area of Pará (TESTON; CORREA, 2015), which points to an increase in the observed richness as a function of increased sampling efforts.

Arctiini's continuous inventory in the Amazonia National Park will contribute to a better understanding of lepidoptera biodiversity in the Amazon biome, and will serve as basic knowledge for conservation strategies for the group in this protected area. Teston and Ferro (2019) suggest intensive collection efforts for tiger moths in this biome.

\section{Acknowledgements}

This publication is part of the RedeLep "Rede Nacional de Pesquisa e Conservação de Lepidópteros", SISBIOTA-Brasil, CNPq (563332/2010-7).

\section{References}

BERNARD, E.; PENNA, L. A. O.; ARAÚJO, E. Downgrading, downsizing, degazettement, and reclassification of protected areas in Brazil. Conservation Biology, San Francisco, v. 28, n. 4, p. 939950, 2014.

BOUBLI, J. P.; HRBEK, T. Introdução à biodiversidade amazônica. In: MARCON, J. L.; MENIN, M.; ARAÚJO, M. G. P. de; HRBEK, T. (Org.). Biodiversidade amazônica: caracterização, ecologia e consevação. Manaus: Edua, 2012. p. 11-17.

BRASIL. Lei no 12.678, de 25 de junho de 2012. Diário Oficial da União, Brasília, v. 149, n. 122, p. 3-6, 2012.

BROWN JR., K. S.; FREITAS, A. V. L. Lepidoptera. In: BRANDÃO, C. R. F.; CANCELLO, E. M. (Ed.). Biodiversity of the State of São Paulo: synthesis of knowledge at the end of the twentieth century. Vol. 5. Invertebrates. São Paulo: FAPESP, 1999. p. 225-243.

CAMARGO, A. J. A. Diversidade de insetos em áreas cultivadas e reserva legal: considerações e recomendações. Boletim de Pesquisa e Desenvolvimento/Embrapa Cerrado, Brasília, v. 1, p. 1-27, 2001.

CARVAlho, T. S.; MAGalhaES, A. S.; DOMingueS, E. P. Desmatamento e a contribuição econômica da floresta na Amazônia. Estudos Econômicos, São Paulo, v. 46, n. 2, p. 499-531, 2016. 
COLWELL, R. K. EstimateS: statistical estimation of species richness and shared species from samples. Version 9.1.0. User's guide and application. 2013. Available in: <http://viceroy. eeb.uconn.edu/estimates/EstimateSPages/EstSUsersGuide/ EstimateSUsersGuide.htm>.

DELFINA, M. C.; TESTON, J. A. Arctiinae (Lepidoptera, Arctiidae) ocorrentes em uma área de pastagem na Amazônia Oriental em Altamira, Pará, Brasil. Acta Amazonica, Manaus, v. 43, n. 1, p. 81-90, 2013.

DRAUDT, M. Familie: Syntomidae. In: SEITZ, A. (Ed). Die GrossSchmetterlinge der Erde. II. Abteilung: Die Gross-Schmetterlinge des Amerikanischen Faunengebietes. 6. Band. Die Amerikanischen Spinner und Schwärmer. Stuttgart: Alfred Kernen, 1914-1919. p. 33-230.

FERRO, V. G.; DINIZ, I. R. Arctiidae (Insecta: Lepidoptera) da Estação Biológica de Boracéia (Salesópolis, São Paulo, Brasil). Biota Neotropica, Campinas, v. 7, n. 3, p. 331-338, 2007.

HAMPSON, G. F. Catalogue of the Lepidoptera Phalaenae in the British Museum. Catalogue of the Syntomidae in the collection of the British Museum. London: Taylor \& Francis, 1898. 559 p.

HAMPSON, G. F. Catalogue of the Lepidoptera Phalaenae in the British Museum. Catalogue of the Arctiadae (Arctianae) and Agaristidae in the collection of the British Museum. London: Taylor \& Francis, 1901. 690 p.

HAMPSON, G. F. Catalogue of the Lepidoptera Phalaenae in the British Museum. Supplement. Volume I. Catalogue of the Amatidae and Arctiadae (Nolinae and Lithosianae) in the collection of the British Museum. London: Taylor \& Francis, 1914. 858 p.

HAMPSON, G. F. Catalogue of the Lepidoptera Phalaenae in the British Museum. Supplement. Volume II. Catalogue of the Lithosiadae (Arctianae) and Phalaenoididae in the collection of the British Museum. London: Taylor \& Francis, 1920. 619 p.

HAWES, J.; MOTTA, C. da S.; OVERAL, W. L.; BARLOW, J.; GARDNER, T. A.; PERES, C. A. Diversity and composition of Amazonian moths in primary, secondary and plantation forest. Journal of Tropical Ecology, Cambridge, v. 25, n. 3, p. 281-300, 2009.

HEPPNER, J. B. Faunal regions and the diversity of Lepidoptera. Tropical Lepidoptera, Gainsville, v. 2, [Supplement], p. 1-85, 1991.

HERING, M. Pericopinae. In: SEITZ, A. (Ed). Die GrossSchmetterlinge der Erde. II. Abteilung: Die Gross-Schmetterlinge des Amerikanischen Faunengebietes. 6. Band. Die Amerikanischen Spinner und Schwärmer. Stuttgart: Alfred Kernen, 1925. p. 425-455.

IBDF. Plano de manejo: Parque Nacional da Amazônia (Tapajós). Brasília: IBDF/POLAMAZONIA, 1978. 154 p.

KASECKER, T.; SILVA, J. M. C. da. Parque Nacional da Amazônia. In: VALENTE, R. de M.; SILVA, J. M. C. da; STRAUBE, F. C.; NASCIMENTO, J. L. X. do (Org.). Conservação de aves migratórias neárticas no Brasil. Belém: Conservação Internacional, 2011. p. 92-95.

KITCHING, R. L.; ORR, A. G.; THALIB L.; MITCHELL, H.; HOPKINS, M. S.; GRAHAM, A. W. Moth assemblages as indicators of environmental quality in remnants of upland
Australian rain forest. Journal of Applied Ecology, London, v. 37, n. 2, p. 284-297, 2000.

MAGURRAN, A. E. Medindo a diversidade biológica. Curitiba: Ed. UFPR, 2011. 261 p.

MORAES, B. C. de; COSTA, J. M. N. da; COSTA, A. L. da; COSTA, M. H. Spatial and temporal variation of precipitation in the State of Pará. Acta Amazonica, Manaus, v. 35, n. 2, p. $207-$ $214,2005$.

MORENO, C.; FERRO, V. G. Arctiinae moths (Lepidoptera, Erebidae) of the Emas National Park, Goiás, Brazil. Biota Neotropica, Campinas, v. 16, n. 2, e20150037, 2016.

SEITZ, A. 4. Familie: Arctiidae, Bärenspinner. In: SEITZ, A. (Ed). Die Gross-Schmetterlinge der Erde. II. Abteilung: Die GrossSchmetterlinge des Amerikanischen Faunengebietes. 6. Band. Die Amerikanischen Spinner und Schwärmer. Stuttgart: Alfred Kernen, 1919-1925. p. 231-497.

TESTON, J. A.; CAMPELO, J. da C.; LOPES, A. M. C.; SPECHT, A. First record of Utetheisa pulchella (Linnaeus, 1758) (Lepidoptera: Erebidae: Arctiinae) in Brazilian Amazon: implications for conservation. Anais da Academia Brasileira de Ciências, Rio de Janeiro, v. 91, n. 1, e20180262, 2019.

TESTON, J. A.; CORREA, D. do C. V. The Arctiini (Lepidoptera, Erebidae, Arctiinae) fauna of the Serra do Pardo National Park, Pará, Brazil. Check List, Rio Claro, v. 11, n. 2, p. 1-9, 2015.

TESTON, J. A.; DELFINA, M. C. Diversidade de Arctiinae (Lepidoptera, Arctiidae) em área alterada em Altamira, Amazônia Oriental, Pará, Brasil. Acta Amazonica, Manaus, v. 40, n. 2, p. 387-396, 2010.

TESTON, J. A.; FERRO, V. G. Arctiini Leach, [1815] (Lepidoptera, Erebidae, Arctiinae) of the Brazilian Amazon. IV - Subtribe Euchromiina Butler, 1876. Biota Neotropica, Campinas, v. 19, n. 4, e20190747, 2019.

TESTON, J. A.; NOVAES, J. B.; ALMEIDA JUNIOR, J. O. B. Abundância, composição e diversidade de Arctinae (Lepidoptera, Arctiidae) em um fragmento de floresta na Amazônia Oriental em Altamira, PA, Brasil. Acta Amazonica, Manaus, v. 42, n. 1, p. $105-$ $114,2012$.

TESTON, J. A.; SPECHT, A.; DI MARE, R. A.; CORSEUIL, E. Arctiinae (Lepidoptera, Arctiidae) coletados em unidades de conservação estaduais do Rio Grande do Sul, Brasil. Revista Brasileira de Entomologia, Curitiba, v. 50, n. 2, p. 280-286, 2006.

VALENTE, D. M. P.; ZENKER, M. M.; TESTON, J. A. Tigermoths in savannas in Eastern Amazon: first assessment of diversity and seasonal aspects. Neotropical Entomology, Londrina, v. 47, n. 6 , p. 842-851, 2018.

VINCENT, B.; LAGUERRE, M. Catalogue of the Neotropical Arctiini Leach, [1815] (except Ctenuchina Kirby, 1837 and Euchromiina Butler, 1876) (Insecta, Lepidoptera, Erebidae, Arctiinae). Zoosystema, Paris, v. 36, n. 2, p. 137-533, 2014.

WATSON, A. An illustrated catalog of the Neotropic Arctiinae types in the United States National Museum (Lepidoptera: Arctiidae) part I. Smithsonian Contributions to Zoology, Washington, v. 50, p. 1-361, 1971.

WATSON, A. An illustrated catalog of the Neotropic Arctiinae types in the United States National Museum (Lepidoptera: Arctiidae) part 
II. Smithsonian Contributions to Zoology, Washington, v. 128, p. 1-160, 1973.

WATSON, A. A reclassification of the Arctiidae and Ctenuchidae formerly placed in the thyretid genus Automolis Hübner (Lepidoptera). With notes on warning coloration and sound. Bulletin of the British Museum Natural History (Entomology), London, v. 25, [Supplement], p. 1-104, 1975.

WATSON, A. A revision of the Halysidota tessellaris species-group (Halysidota sensu stricto) (Lepidoptera: Arctiidae). Bulletin of the British Museum Natural History (Entomology), London, v. 40, p. 1-65, 1980.
WATSON, A.; FLETCHER, D. S.; NYE, I. W. B. Noctuoidea: Arctiidae, Cocytiidae, Ctenuchidae, dilobidae, Dioptidae, lymantriidae, Notodontidae, Strepsimanidae, Thaumetopoeidae \& Thyretidae. In: NYE, I. W. B. (Ed). The generic names of moths of the world. London: The Natural History Museum, 1995. p. 1-228.

WELLER, S. J.; SIMMONS, R. B.; BOADA, R.; CONNER, W. E. Abdominal modifications occurring in wasp mimics of the Ctenuchine-Euchromiine clade (Lepidoptera: Arctiidae). Annals of the Entomological Society of America, Washington, v. 93, n. 4, p. $920-928,2000$. 